\title{
Undisturbed and disturbed above canopy ponderosa pine emissions: PTR-TOF-MS measurements and MEGAN 2.1 model results
}

\author{
L. Kaser ${ }^{1,2}$, T. Karl ${ }^{2, *}$, A. Guenther ${ }^{2}$, M. Graus ${ }^{3,4}$, R. Schnitzhofer ${ }^{1}$, A. Turnipseed ${ }^{2}$, L. Fischer ${ }^{5}$, P. Harley ${ }^{2}$, \\ M. Madronich ${ }^{2}$, D. Gochis ${ }^{6}$, F. N. Keutsch ${ }^{7}$, and A. Hansel ${ }^{1}$ \\ ${ }^{1}$ Institute for Ion Physics and Applied Physics, University of Innsbruck, Innsbruck, Austria \\ ${ }^{2}$ Atmospheric Chemistry Division, National Center for Atmospheric Research, Boulder, CO, USA \\ ${ }^{3}$ Chemical Sciences Division, NOAA Earth System Research Laboratory, Boulder, CO, USA \\ ${ }^{4}$ Cooperative Institute for Research in Environmental Sciences (CIRES), University of Colorado, Boulder, CO, USA \\ ${ }^{5}$ Ionimed Analytik GmbH, Innsbruck, Austria \\ ${ }^{6}$ Research Application Laboratory, National Center for Atmospheric Research, Boulder, CO, USA \\ ${ }^{7}$ Department of Chemistry, University of Wisconsin-Madison, Madison, WI, USA \\ *now at: Institute of Meteorology and Geophysics, University of Innsbruck, Innsbruck, Austria
}

Correspondence to: A. Hansel (armin.hansel@uibk.ac.at)

Received: 16 May 2013 - Published in Atmos. Chem. Phys. Discuss.: 11 June 2013

Revised: 22 October 2013 - Accepted: 1 November 2013 - Published: 9 December 2013

\begin{abstract}
We present the first eddy covariance flux measurements of volatile organic compounds (VOCs) using a proton-transfer-reaction time-of-flight mass spectrometer (PTR-TOF-MS) above a ponderosa pine forest in Colorado, USA. The high mass resolution of the PTR-TOF-MS enabled the identification of chemical sum formulas. During a 30 day measurement period in August and September 2010, 649 different ion mass peaks were detected in the ambient air mass spectrum (including primary ions and mass calibration compounds). Eddy covariance with the vertical wind speed was calculated for all ion mass peaks. On a typical day, 17 ion mass peaks, including protonated parent compounds, their fragments and isotopes as well as VOC- $\mathrm{H}^{+}$-water clusters, showed a significant flux with daytime average emissions above a reliable flux threshold of $0.1 \mathrm{mg}$ compound $\mathrm{m}^{-2} \mathrm{~h}^{-1}$. These ion mass peaks could be assigned to seven compound classes. The main flux contributions during daytime (10:0018:00 LT) are attributed to the sum of 2-methyl-3-buten-2ol (MBO) and isoprene (50\%), methanol (12\%), the sum of acetic acid and glycolaldehyde $(10 \%)$ and the sum of monoterpenes $(10 \%)$. The total MBO + isoprene flux was composed of $10 \%$ isoprene and $90 \% \mathrm{MBO}$.

There was good agreement between the light- and temperature dependency of the sum of MBO and isoprene observed for this work and those of earlier studies. The above canopy
\end{abstract}

flux measurements of the sum of $\mathrm{MBO}$ and isoprene and the sum of monoterpenes were compared to emissions calculated using the Model of Emissions of Gases and Aerosols from Nature (MEGAN 2.1). The best agreement between MEGAN 2.1 and measurements was reached using emission factors determined from site-specific leaf cuvette measurements. While the modeled and measured $\mathrm{MBO}+$ isoprene fluxes agree well, the emissions of the sum of monoterpenes is underestimated by MEGAN 2.1. This is expected as some factors impacting monoterpene emissions, such as physical damage of needles and branches due to storms, are not included in MEGAN 2.1.

After a severe hailstorm event, 22 ion mass peaks (attributed to six compound classes plus some unknown compounds) showed an elevated flux for the two following days. The sum of monoterpene emissions was 4-23 times higher compared to emissions prior to the hailstorm while MBO emissions remained unchanged. The monoterpene emission (in $\mathrm{mg}$ compound $\mathrm{m}^{-2}$ ) during this measurement period is underestimated by $40 \%$ if the effect of this disturbance source is not considered. 


\section{Introduction}

A great variety of volatile organic compounds (VOCs) is continuously emitted into the atmosphere by pyrogenic, anthropogenic and biogenic sources. Due to their central role in tropospheric ozone chemistry and their ability to form aerosols, they can influence local and global climate (Koppmann, 2007). Globally, total biogenic VOC sources are considered to be approximately ten times larger than the sum of anthropogenic emissions (Muller, 1992; Olivier et al., 1999; Guenther, 2002; Lamarque et al., 2010). While terpenoids such as hemiterpenes, monoterpenes and sesquiterpenes are an important fraction of biogenic VOCs (BVOCs), other compounds such as oxygenated compounds (methanol, acetone, acetaldehyde) also exhibit significant emissions from the biosphere (Fowler et al., 2009, and references therein). In the last decade, BVOC emissions from the biosphere have been measured using proton-transfer-reaction mass spectrometer (PTR-MS) instruments, which allow monitoring a selected set of ion mass peaks that are related to different compounds based on disjunct eddy covariance flux measurements (e.g., Karl et al., 2002). The recent development of a proton-transfer-reaction time-of-flight mass spectrometer (PTR-TOF-MS) (Jordan et al., 2009; Graus et al., 2010) enables measurements of the entire mass spectrum within a fraction of a second, allowing $10 \mathrm{~Hz}$ eddy covariance measurements over a wide mass range. Additionally, the high mass resolution of the time-of-flight mass spectrometer allows for separation of isobaric compounds. So far this instrument has been tested for flux measurements above grassland (Müller et al., 2010; Ruuskanen et al., 2011; Bamberger et al., 2011) and above a citrus plantation (Park et al., 2013). Ruuskanen et al. (2011) and Park et al. (2013) report fluxes (emissions and depositions) for up to 30 (27) different ion mass peaks corresponding to a dozen different VOC species. Müller et al. (2010) and Park et al. (2013) evaluated eddy covariance measurements by PTR-TOF-MS by comparing with the well-established disjunct eddy covariance technique using PTR-MS. Both studies showed good agreement between the two techniques.

Pine trees are widespread in forests throughout the Northern Hemisphere and are a dominant component of about $62 \%$ of US woodlands where they cover an area of about 2.4 million $\mathrm{km}^{2}$ (Guenther et al., 1994). Ponderosa pine is the principle tree species in over 0.1 million $\mathrm{km}^{2}$ in the US and is present in an additional 0.15 million $\mathrm{km}^{2}$ (Graham and Jain, 2005).

Ponderosa pine forest BVOC fluxes of monoterpenes, 2methyl-3-buten-2-ol (MBO), methanol, ethanol, acetaldehyde and acetone have been previously measured at a site in the California Sierra Nevada (Schade et al., 1999; Schade and Goldstein, 2001; Lee et al., 2005). The magnitude and type of compounds emitted by plants is complex, depending on the species, the age, and the health of the vegetation. Effects of short-term variations in temperature, moisture and light levels (Guenther et al., 1995; Kesselmeier and Staudt, 1999; Niinemets et al., 2010a) are better understood. Studies have shown that temperature is the main driver for monoterpene emissions, while both temperature and light are important for MBO emissions. These studies took place in ponderosa pine forests using above canopy relaxed eddy accumulation flux measurements (Schade and Goldstein, 2001) and leaf level measurements (Harley et al., 1998). These observations are typically used to develop emission models such as the Model of Emissions of Gases and Aerosols from Nature (MEGAN), which uses leaf area index (LAI), light, temperature, humidity, wind speed, soil moisture and average canopy environmental conditions of the past 24 to $240 \mathrm{~h}$ to calculate emissions of VOCs from ecosystems to the atmosphere (Guenther et al., 2006, 2012).

Additionally, abiotic and biotic stress factors such as drought, herbivore infestation, severe storms, mechanical wounding, air pollutants, etc. can initially enhance VOC emissions of plants although chronic stress may eventually reduce emissions (Niinemets, 2010; Niinemets et al., 2010b; Holopainen and Gershenzon, 2010; Duhl et al., 2013). Most emission measurements have focused on VOC emissions of intact and undamaged plants; however, studies by Schade and Goldstein (2003), Räisänen et al. (2008) and Kim et al. (2011) demonstrated enhanced monoterpene fluxes after mechanical wounding on the ecosystem scale. A few studies also reported enhanced mixing ratios of monoterpenes and sesquiterpenes after severe storms (Helmig et al., 1998; Bouvier-Braun et al., 2009; Haase et al., 2011; and Bamberger et al., 2011). Holzinger et al. (2006) reported increased monoterpene emissions on days following rain events. While temperature- and light-dependent emissions of VOCs are well understood, the prediction of emissions induced by stress factors is complicated (Grote and Niinemets, 2008). The development of emission algorithms to account for ecosystem disturbance in biogenic emission models requires the availability of representative leaf, plant and ecosystem scale measurements (Arneth and Niinemets, 2010). Niinemets et al. (2010b) highlight the importance of measurements in order to reduce model uncertainties related to stress, environmental variability, seasonality and foliage developmental stage.

In this paper we present above canopy flux measurements of light- and temperature-driven emissions of BVOCs from a ponderosa pine forest during 30 days in August/September 2010. We compare these to emissions calculated with the MEGAN 2.1 model using default parameters and values based on land cover and enclosure measurements at the same site. We also report enhanced BVOC emissions after a severe hailstorm that damaged needles and branches. Our canopy flux measurements serve as a starting point to evaluate the magnitude of these stress driven emission events. 


\section{Methods}

\subsection{Field site}

VOC eddy covariance measurements were conducted at the Manitou Forest Observatory located in the US Forest Service Manitou Experimental Forest near Woodland Park, Colorado, USA ( $2300 \mathrm{~m}$ elevation, lat. $39^{\circ} 6^{\prime} 2.34^{\prime \prime} \mathrm{N}$, long. $\left.105^{\circ} 6^{\prime} 8.94^{\prime \prime}\right)$ as part of the Bio-Hydro-Atmosphere Interactions of Energy, Aerosols, Carbon, $\mathrm{H}_{2} \mathrm{O}$, Organics and Nitrogen (BEACHON) Rocky Mountain Organic Carbon Study (ROCS) campaign in summer 2010. The field site has been described in detail elsewhere (see Kim et al., 2010; DiGangi et al., 2011). An extensive overview on VOC concentration measurements at this site has been summarized by Kaser et al. (2013). Ponderosa pine trees about $100 \mathrm{yr}$ in age and with an average height of $18.5 \mathrm{~m}$ dominate BVOC emissions within the flux footprint. The canopy is open and of varying density. The ground surface is covered by grasses, sage, forbs and exposed cryptogrammic soils. The typical leaf area index (LAI) for tree canopies is 3 and the tree cover fraction is 0.38 , resulting in a landscape average LAI at this site of approximately 1.14 .

Here we present 30 days of VOC flux measurements between 3 August and 8 September 2010. VOC fluxes were not measured between 25 August-28 August and 31 August-2 September, when the PTR-TOF-MS was used for other measurements.

\subsection{Instrumentation and calibration}

VOC measurements with $10 \mathrm{~Hz}$ time resolution allowing the calculation of eddy covariance fluxes were conducted on a walk-up chemistry tower at $25.1 \mathrm{~m}$ height. A $35 \mathrm{~m}$ long unheated Teflon line (OD: 3/8 in., 20 SLPM) was mounted $20 \mathrm{~cm}$ below the sonic anemometer. VOC volume mixing ratios were measured by a PTR-TOF-MS located at the bottom of the tower in a sea container laboratory. Details on the instrument, calibration and instrument performance can be found in Kaser et al. (2013) and will be mentioned here only briefly. The PTR-TOF-MS developed at the University of Innsbruck (Graus et al., 2010) was operated under standard conditions at a drift tube temperature of $60^{\circ} \mathrm{C}, 580 \mathrm{~V}$ drift voltage and $2.3 \mathrm{mbar}$ drift tube pressure corresponding to an $E / N$ of $125 \mathrm{Td}$ ( $E$ being the electric field strength and $N$ the gas number density; $1 \mathrm{Td}=10^{-17} \mathrm{~V} \mathrm{~cm}^{2}$ ). The PTR-TOF-MS was calibrated weekly by dynamic dilution of VOCs using a quantitative gas standard provided by the US National Oceanic and Atmospheric Administration (NOAA, Boulder, CO, USA) containing methanol, acetonitrile, acetaldehyde, acetone, methyl vinyl ketone, limonene, MBO, pyrrole, benzene, toluene and methyl ethyl ketone. Background measurements were conducted by sampling ambient air through a catalytic converter for $25 \mathrm{~min}$ every $7 \mathrm{~h}$. There were no compressed gas standards available for some com- pounds like acetic acid or ethanol. These compounds were calibrated using a gas standard generator, the liquid calibration unit (LCU, Ionimed Analytik, Innsbruck). The LCU uses a liquid standard that can be easily mixed in-house from a targeted substance using volumetric methods. This liquid sample is efficiently vaporized into zero air gas by a nebulizer, producing a calibration gas stream. The liquid standard and zero air gas flows are both regulated in order to obtain welldefined concentrations of VOCs. The evaporation takes place in a heated chamber in order to ensure complete evaporation of the contained compounds. Depending on their solubility in water and their vapor pressure, many compounds can be calibrated from the ppbv to the \%o range at a humidity between 1 to $50 \mathrm{~g} \mathrm{~m}^{-3}$ (Fischer et al., 2013).

Full PTR-TOF-MS mass spectra were recorded up to $\mathrm{m} / \mathrm{z}$ 315 with $10 \mathrm{~Hz}$ time resolution. Mass scale calibration using additionally added di- and trichlorobenzene ion mass peaks was conducted every 6 min. Data evaluation specific to eddy covariance flux calculations was conducted using Matlab (Mathworks, USA) routines, described in detail by Müller et al. (2010) and Ruuskanen et al. (2011).

The three-dimensional winds and temperature were measured using a three-dimensional sonic anemometer CSAT-3 (Campbell Scientific) with $10 \mathrm{~Hz}$ resolution. Photosynthetically active radiation (PAR) and air temperature were measured at $27.8 \mathrm{~m}$ and $25 \mathrm{~m}$ height using a Li190a quantum sensor (Li-Cor, USA) and an HMP35C-2 (Campbell Scientific, USA) respectively.

Two different types of precipitation measurements were made at the site. The first sensor used for measuring quantitative total precipitation amounts was an altershielded, weighing-type total precipitation gauge (Environmental Technologies Inc., Noah-II). This sensor captures all falling precipitation and provides a measure of its liquid water equivalent. To distinguish between hail and rainfall an acoustic-type precipitation sensor (Vaisala, WXT RAINCAP) was used. This sensor analyses the acoustic signature of hydrometeors impacting the sensor head surface and, for solid particles such as hail, provides a total count of hailstone impacts. Also, a laser ranging sensor (Jenoptik AG SHM30 laser snow depth sensor) was deployed at the site to measure winter snowfall as well as hail accumulations on the ground. The sensor suggests that approximately $1.4 \mathrm{~cm}$ of hail accumulated on the ground during the main hail event on $4 \mathrm{Au}-$ gust 2010 presented below.

\subsection{Flux calculation}

Eddy covariance fluxes ( $30 \mathrm{~min}$ values) were calculated for 649 ion mass peaks from the $10 \mathrm{~Hz}$ PTR-TOF-MS signals and the $10 \mathrm{~Hz}$ sonic anemometer data, according to Karl et al. (2002) and Ruuskanen et al. (2011). Three-dimensional wind data were recorded on a second computer. Only the PTR-TOF-MS computer time was synchronized with an online time server. The timestamp of the laptop recording the 


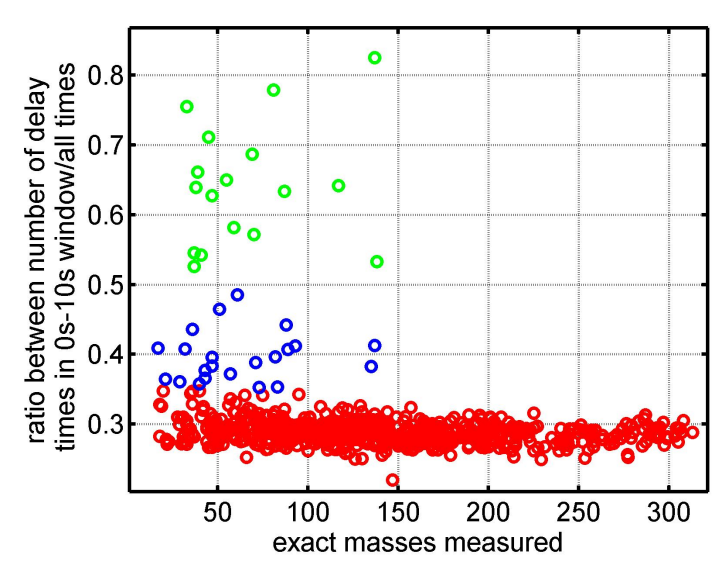

Fig. 1. Fraction of physically plausible delay times as a function of recorded exact ion mass peaks. Green circles (classified as grade A flux) indicate ion mass peaks that were recorded more than $50 \%$ of the time, having a physically plausible delay time in the range of 0 to $10 \mathrm{~s}$. Blue circles are grade B fluxes and red circles represent the majority of ion mass peaks that did not show a significant flux during the measurement campaign from 4 August to 8 September 2010 .

wind data drifted and was reset periodically to match the VOC computer throughout the measurement period. These reset points where used as benchmarks to correct the relative drift in time between the two measurements. The threedimensional wind vector was rotated on a 5-hourly basis according to Wilczak et al. (2001). To detect fluxes among the 649 ion mass peaks, we developed a screening method based on the delay times that occur from the covariance analysis of the individual ion mass peaks and the corresponding vertical wind speed during $30 \mathrm{~min}$ time intervals. In order to obtain ion mass peaks that show a significant covariance between the vertical wind and their volume mixing ratio, we allowed the flux calculation routine to choose a maximum or minimum of the covariance peak within a delay-time window of max. $\pm 20 \mathrm{~s}$. The physically meaningful delay-time window ( 0 to $10 \mathrm{~s})$ was defined as the maximum difference between the two computer clocks used for wind and VOC measurements and the maximum delay time caused by the $35 \mathrm{~m}$ long sampling line. We used these delay times to determine ion mass peaks exhibiting a significant flux or no flux. For this purpose the fraction of half-hour values where the delay time was found in the physically meaningful delay-time window between 0 to $10 \mathrm{~s}$ was used to attribute all ion mass peaks to an individual flux grade. This fraction is plotted in Fig. 1. For example, the delay time of the exact ion mass peak $m / z 69.0704\left(\mathrm{C}_{5} \mathrm{H}_{9}^{+}\right)$which corresponds to the sum of isoprene (protonated isoprene) plus $\mathrm{MBO}$ (protonated $\mathrm{MBO}$ minus $\mathrm{H}_{2} \mathrm{O}$ ) was found $70 \%$ of the time within the 0 to $10 \mathrm{~s}$ window.
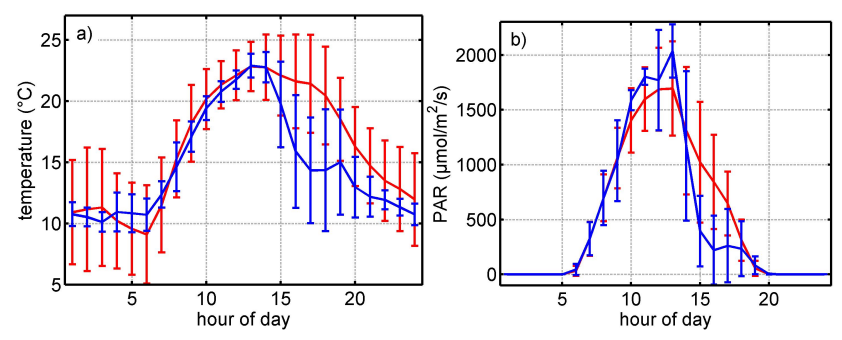

Fig. 2. Diurnal cycles of temperature (a) and PAR (b) during the 30 day period of VOC flux measurements (red) and on the day of the hailstorm and the following two days (blue). Data points and error bars represent mean values and standard deviation in each half hour, respectively.

Ion mass peaks where the above described fraction was smaller than $35 \%$ do not exhibit a significant covariance between vertical wind and volume mixing ratio and are depicted by red circles. These ion mass peaks exhibit no flux or fluxes that are close to or below the limit of detection for most of the time and are classified as grade $\mathrm{C}$ flux. Blue circles depict ion mass peaks for which a physically meaningful covariance between vertical wind and volume mixing ratio can be found for at least $35 \%$ of all measured half-hour values. We rank these as grade B fluxes. Green circles were defined as ion mass peaks where a physically meaningful delay time was found for more than $50 \%$ of all measured half hour flux values. We rank these as grade A flux ion mass peaks. A second criterion was defined such that we do not consider fluxes $<0.1 \mathrm{mg}$ compound $\mathrm{m}^{-2} \mathrm{~h}^{-1}$ in this work as influences from advective fluxes cannot be conclusively excluded at these low levels. VOC gradient measurements were used to estimate the magnitude of the total advection flux based on vertical advection. Vertical advection was calculated to be in the range of $0.04-0.1 \mathrm{mg}$ compound $\mathrm{m}^{-2} \mathrm{~h}^{-1}$. Since we do not have the means to constrain the influence of advective fluxes (other than estimating their magnitude), we defined this criterion as a conservative cutoff limit.

\section{Results}

\subsection{Meteorology}

Figure 2 depicts a typical diurnal cycle for temperature- and photosynthetically active radiation (PAR) during the VOC flux measurement period. During the 30 days of flux measurements, average air temperatures reached a maximum of $23^{\circ} \mathrm{C}$ at 1 p.m. (Mountain standard time, MST) and a minimum of $9^{\circ} \mathrm{C}$ at 6 a.m. (MST).

On average, PAR reaches a maximum of $1700 \mu \mathrm{mol} \mathrm{m}^{-2} \mathrm{~s}^{-1}$ at 1 p.m. (MST). Typically, days were sunny with some cloudiness as well as rainfall during some afternoons. This is visible in the average diurnal PAR cycle, which has a slight dip in the afternoon. On 4 August 


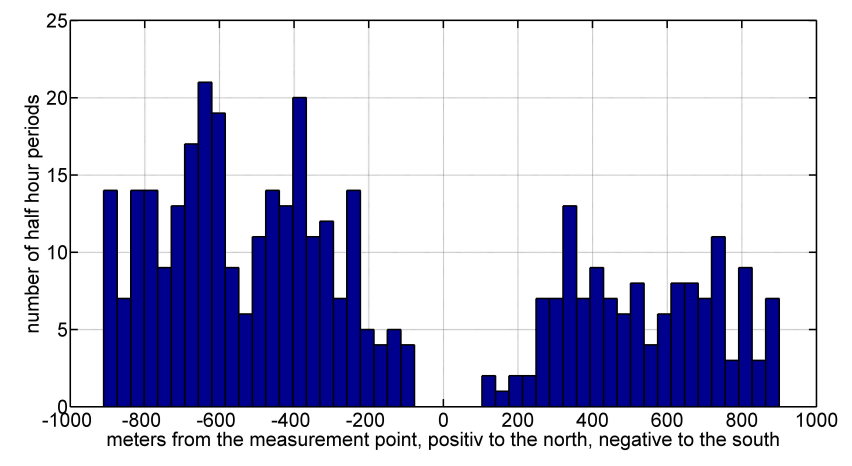

Fig. 3. All half-hour values for the $90 \%$ flux recovery during the unstable atmospheric conditions lie within $900 \mathrm{~m}$. Negative values indicate the distance in meters from the flux tower to the south, positive from the tower to the north.

the site experienced a severe hailstorm with hailstones of $1-3 \mathrm{~cm}$ in diameter, which caused significant damage to needles and branches. During the two days following the hail storm (Fig. 2, blue curves), temperature and PAR reached the typically observed midday maxima of $23^{\circ} \mathrm{C}$ and $2000 \mu \mathrm{mol} \mathrm{m} \mathrm{m}^{-2} \mathrm{~s}^{-1}$, respectively, but both decreased rapidly in the afternoon.

Flux data during the hailstorm and the following two days are treated in Sect. 3.5. Estimates of emission factors and discussion of typical fluxes in Sect. 3.3 are based on data after 7 August when the effect of the hailstorm had decreased.

Generally the weather changed from some cloudiness and rain during the beginning of the measurement period to dry and sunny at the end of the campaign. Precipitation events with more than $2 \mathrm{~mm}$ water occurred only on 27 July (hail), 4 August (hail), 5 August (rain) and 9 August (rain). Maximum daytime temperatures remained similar over the measurement period but nighttime temperatures decreased gradually from $10^{\circ} \mathrm{C}$ to $4^{\circ} \mathrm{C}$ due to the approaching autumn.

\subsection{Footprint and quality control}

The flux footprint was calculated using the $90 \%$ flux recovery value according to Hsieh et al. (2000). The canopy height was $18.5 \mathrm{~m}$. The zero plane displacement, $12.7 \mathrm{~m}$, was defined as $2 / 3$ of the average canopy height.

For the momentum roughness height, we used $8 \%$ of the canopy height. The ratio between $z_{m}$ (measurement height above the zero plane displacement) and the Obukhov length $(L)$ was used to distinguish between stable $\left(\mathrm{z}_{\mathrm{m}} / L>0\right)$ and unstable $\left(\mathrm{z}_{\mathrm{m}} / L<0\right)$ atmospheric conditions. The calculated footprint was $<900 \mathrm{~m}$ during unstable conditions $(45 \%$ of the measurement time) and $<2500 \mathrm{~m}$ for stable conditions $(55 \%)$. Figure 3 shows the footprint in more detail for unstable atmospheric conditions. Data points are grouped along the main valley wind direction coming from the north (positive axis: $270^{\circ}$ to $90^{\circ}$ ) and from the south (negative axis: $90^{\circ}$ to $270^{\circ}$ ).
Quality control for the flux data included some criteria that are mass independent (1-4) as well as mass dependent (5-6). Data were removed if (1) wind came from east $\left(35-145^{\circ}\right.$ for unstable conditions, $10-170^{\circ}$ for stable conditions) to eliminate any contribution from a lightly traveled highway approximately $500 \mathrm{~m}$ to the east of the field site; if (2) the calculated footprint was larger than $1850 \mathrm{~m}$ (occurring during stable conditions) as the vegetation changes slowly outside this radius; if (3) 30 out of 18000 wind data points per half hour are outside $5 \sigma$ of the mean to eliminate spikes in wind data; if (4) the third rotation angle exceeded $\pm 10 \%$ (McMillen, 1988); if (5) 30 out of 18000 VOC volume mixing ratios per half hour are outside $5 \sigma$ of the mean to eliminate spikes in concentration data; and if (6) the stationarity test exceeded $60 \%$ (Foken and Wichura, 1996). Depending on the individual compound, between 33-55\% of all half-hour flux values passed these quality criteria (Table 1). For MBO we calculated a daytime limit of detection of $0.15 \mathrm{mg} \mathrm{m}^{-2} \mathrm{~h}^{-1}$ and an advection flux of $0.07 \mathrm{mg} \mathrm{m}^{-2} \mathrm{~h}^{-1}$.

\subsection{Light- and temperature-driven emissions}

Ion mass peaks showing a significant correlation with the vertical wind component were determined as described in Sect. 2.3. After filtering out all ion mass peaks that (1) are related to primary ions (including those masked by a water flux interference) or (2) do not pass the delay time criterion described in Sect. 2.3 or (3) have an average daytime flux $<0.1 \mathrm{mg} \mathrm{m}^{-2} \mathrm{~h}^{-1}$, we obtain 11 grade A flux ion mass peaks (Table 1 - bold) and six grade B flux ion mass peaks (Table 1 - italic). Table 1 lists these ion mass peaks by descending flux magnitude grouped by likely compounds. As an example, MBO and isoprene show a flux on the protonated MBO parent mass peak $(m / z 87.0811)$, the protonated isoprene and MBO fragment mass peak $(m / z$ 69.0704) and the fragment mass peak $(m / z 41.0400)$ as well as the isotopes $(m / z$ 88.0824, $m / z$ 70.0729). After unravelling isotopic patterns and fragments, we obtain seven different compounds or compound classes emitted by this ecosystem during daytime.

Diurnal cycles for all 7 compounds showing a significant flux are depicted in Fig. 4. The emissions are dominated by the sum of $\mathrm{MBO}$ and isoprene, accounting for $50 \%$ of the daytime emissions. When using a PTR-TOF-MS operated in $\mathrm{H}_{3} \mathrm{O}^{+}$mode the fragment of protonated $\mathrm{MBO}$ exhibits the same ion mass peak as protonated isoprene. Therefore the sum of MBO and isoprene is given. Using the calibrated fragmentation pattern of $\mathrm{MBO}$ and comparing it to the ratio of $m / z 69.0704$ and $m / z 87.0811$ measured in ambient air, it is possible to estimate the isoprene flux at this site. During the measurements in summer 2010, $10 \%$ of the total $\mathrm{MBO}+$ isoprene flux can be attributed to isoprene. Other BVOC fluxes include methanol (11\%), the sum of acetic acid and glycolaldehyde (10\%), the sum of monoterpenes $(10 \%)$, the sum of acetone and propanal $(7 \%)$, ethanol $(5 \%)$ and acetaldehyde $(5 \%)$. Formaldehyde flux measurements 
Table 1. Volatile organic compounds showing an emission flux during the period of 5 August to 8 September 2010. Grade A fluxes (bold) and grade B fluxes (italic) are listed with sum formula and proposed compound.

\begin{tabular}{|c|c|c|c|c|c|c|c|c|c|}
\hline $\begin{array}{l}\text { Molecular } \\
\text { formula }\end{array}$ & $\begin{array}{l}\text { Likely } \\
\text { compound }\end{array}$ & $\begin{array}{l}\text { Parent ion } \\
(m / z)\end{array}$ & $\begin{array}{l}\text { Fragment } \\
(m / z)\end{array}$ & $\begin{array}{l}\text { Isotopo- } \\
\text { logue } \\
(m / z)\end{array}$ & $\begin{array}{l}\text { Water } \\
\text { cluster } \\
(m / z)\end{array}$ & $\begin{array}{l}\text { flux }(m g \\
\left.m^{-2} h^{-1}\right)^{a}\end{array}$ & $\begin{array}{l}\text { Percent } \\
\text { data } \\
\text { used }^{b}\end{array}$ & $\begin{array}{l}\text { Calibration } \\
\text { method }\end{array}$ & $\begin{array}{l}\text { Sensitivity } \\
\left(\text { ncps ppbv }^{-1}\right)\end{array}$ \\
\hline $\mathrm{C}_{5} \mathrm{H}_{10} \mathrm{O}-\mathrm{H}^{+}$ & $\begin{array}{l}\mathrm{MBO} \text { and } \\
\text { isoprene }\end{array}$ & 87.0811 & $\begin{array}{l}69.0704 \\
41.0400\end{array}$ & $\begin{array}{l}88.0824 \\
\mathbf{7 0 . 0 7 2 9}\end{array}$ & & 1.84 & 40 & $\begin{array}{l}\text { Gas } \\
\text { standard }\end{array}$ & 13.5 \\
\hline $\mathrm{CH}_{4} \mathrm{O}-\mathrm{H}^{+}$ & Methanol & 33.0336 & & & 51.0438 & 0.42 & 47 & $\begin{array}{l}\text { Gas } \\
\text { standard }\end{array}$ & 11.7 \\
\hline $\mathrm{C}_{2} \mathrm{H}_{2} \mathrm{O}-\mathrm{H}^{+}$ & $\begin{array}{l}\text { acetic acid } \\
\text { and glycolaldehyde }\end{array}$ & 61.0287 & 43.0180 & & & 0.36 & 36 & LCU & 7.4 \\
\hline $\mathrm{C}_{10} \mathrm{H}_{16}-\mathrm{H}^{+}$ & $\begin{array}{l}\text { sum of } \\
\text { monoterpenes }\end{array}$ & 137.134 & $\begin{array}{l}\mathbf{8 1 . 0 7 0 6} \\
95.0866\end{array}$ & $\begin{array}{l}\mathbf{1 3 8 . 1 3 7} \\
82.0738\end{array}$ & & 0.35 & 33 & $\begin{array}{l}\text { Gas } \\
\text { standard }\end{array}$ & 13.1 \\
\hline $\mathrm{C}_{3} \mathrm{H}_{6} \mathrm{O}-\mathrm{H}^{+}$ & $\begin{array}{l}\text { acetone and } \\
\text { propanal }\end{array}$ & 59.0495 & & & & 0.27 & 39 & $\begin{array}{l}\text { Gas } \\
\text { standard }\end{array}$ & 19.7 \\
\hline $\mathrm{C}_{2} \mathrm{H}_{6} \mathrm{O}-\mathrm{H}^{+}$ & Ethanol & 47.0469 & & & & 0.17 & 39 & LCU & 2.5 \\
\hline $\mathrm{C}_{2} \mathrm{H}_{4} \mathrm{O}-\mathrm{H}^{+}$ & Acetaldehyde & 45.0337 & & & & 0.17 & 50 & $\begin{array}{l}\text { Gas } \\
\text { standard }\end{array}$ & 17.8 \\
\hline
\end{tabular}

a Daytime (10-18 h) average flux (mg compound $\left.\mathrm{m}^{-2} \mathrm{~h}^{-1}\right) ;{ }^{\mathrm{b}}$ percentage of datapoints used after quality control.

published by DiGangi et al. (2011) contribute $2 \%$ of the total observed BVOC emission with a mean daytime emission of $0.08 \mathrm{mg} \mathrm{m}^{-2} \mathrm{~h}^{-1}$.

As shown by Harley et al. (1998) and Schade et al. (2001), MBO emissions are light (Eq. 1) and temperature dependent (Eq. 2), and these dependencies are well described by the following expressions.

$C_{L}=\frac{\alpha \cdot C_{L_{1}} \cdot L}{\sqrt{1+\alpha^{2} \cdot L^{2}}}$

$C_{L}$ is a scalar that accounts for the emission affected by PAR; $\alpha$ and $C_{L_{1}}$ are empirical coefficients and $L$ is PAR.

$C_{T}=\frac{E_{\mathrm{opt}} \cdot C_{T_{2}} \cdot e^{C_{T_{1}} \cdot x}}{C_{T_{2}}-C_{T_{1}} \cdot\left(1-e^{C_{T_{2}} x}\right)}, x=\frac{\frac{1}{T_{\mathrm{opt}}}-\frac{1}{T}}{R}$

$C_{T}$ accounts for the emission influenced by temperature. $E_{\text {opt }}$ is the emission capacity at the temperature $T_{\text {opt }}, T$ the temperature, $R$ the ideal gas constant, and $C_{T_{1}}, C_{T_{2}}$ the empirical coefficients.

To calculate light dependencies, data from a narrow temperature range (e.g., $23-27^{\circ} \mathrm{C}$ ) were chosen and the remaining data were binned into $100 \mu \mathrm{mol} \mathrm{m}^{-2} \mathrm{~s}^{-1}$ light steps. Similarly for the temperature dependence, only data for which PAR exceeded $1000 \mu \mathrm{mol} \mathrm{m}{ }^{-2} \mathrm{~s}^{-1}$ were taken and binned into $1^{\circ} \mathrm{C}$ temperature windows.

A comparison of the light dependence of our measurements between $23-27^{\circ} \mathrm{C}$ with previous measurements and MEGAN 2.1 is shown in Fig. 5 and summarized in Table 2. The Harley et al. (1998) light curve represents leaf level measurements; MBO emissions increase nearly linearly up to around $1000 \mu \mathrm{mol} \mathrm{m}{ }^{-2} \mathrm{~s}^{-1}$ before reaching a plateau. In contrast, canopy scale fluxes are expected to continue to increase with increasing PAR because of the assumption that not all leaves are receiving the full sunlight because they can
Table 2. Comparison of the empirical coefficients from the lightdependent MBO and isoprene emission following Eq. (1).

\begin{tabular}{lrrrr}
\hline & $\begin{array}{r}\text { Harley et al. } \\
(1998)\end{array}$ & $\begin{array}{r}\text { Schade et al. } \\
(2001)\end{array}$ & This work & MEGAN 2.1 \\
\hline$\alpha$ & 0.0011 & 0.0011 & $0.0011 \pm 0.0002$ & 0.0007 \\
$\mathrm{C}_{L_{1}}$ & 1.44 & 1.37 & $1.35 \pm 0.08$ & 1.74 \\
\hline
\end{tabular}

Table 3. $\mathrm{MBO}+$ isoprene light dependence of fitted data for four different temperature regimes.

\begin{tabular}{lccc}
\hline $\mathrm{MBO}+$ isoprene & $\alpha$ & $\mathrm{C}_{L_{1}}$ & $r^{2}$ \\
\hline $17-19^{\circ} \mathrm{C}$ & $0.0009 \pm 0.0002$ & $1.49 \pm 0.17$ & 0.83 \\
$19-21^{\circ} \mathrm{C}$ & $0.0007 \pm 0.0002$ & $1.74 \pm 0.24$ & 0.85 \\
$21-23^{\circ} \mathrm{C}$ & $0.0005 \pm 0.0002$ & $2.23 \pm 0.46$ & 0.86 \\
$23-27^{\circ} \mathrm{C}$ & $0.0011 \pm 0.0002$ & $1.35 \pm 0.08$ & 0.90 \\
\hline
\end{tabular}

be shaded by other leaves and because they can be oriented at various angles to the direct solar beam. Against this expectation, our canopy scale light curve and that of Schade et al. (2001) are almost exactly the same as the Harley et al. (1998) leaf level light curve. This could imply that in a relatively open needle leaf canopy such as the ponderosa pine, there is no or very little shading of the needles within the canopy. The light dependency used in MEGAN 2.1 assumes shading of the leaves and is therefore not yet reaching saturation at $1000 \mu \mathrm{mol} \mathrm{m}{ }^{-2} \mathrm{~s}^{-1}$. A different light-dependent behavior is found for different temperature ranges, as shown in Table 3. From the 4 different temperature ranges $\left(17-19^{\circ} \mathrm{C}\right.$, $19-21^{\circ} \mathrm{C}, 21-23^{\circ} \mathrm{C}$ and $23-27^{\circ} \mathrm{C}$ ), the results from 19$21^{\circ} \mathrm{C}$ agree best with MEGAN 2.1 and $23-27^{\circ} \mathrm{C}$ best with the earlier leaf level and above canopy measurements.

The normalized temperature dependence of our above canopy $\mathrm{MBO}+$ isoprene fluxes is shown in Fig. 6 and 

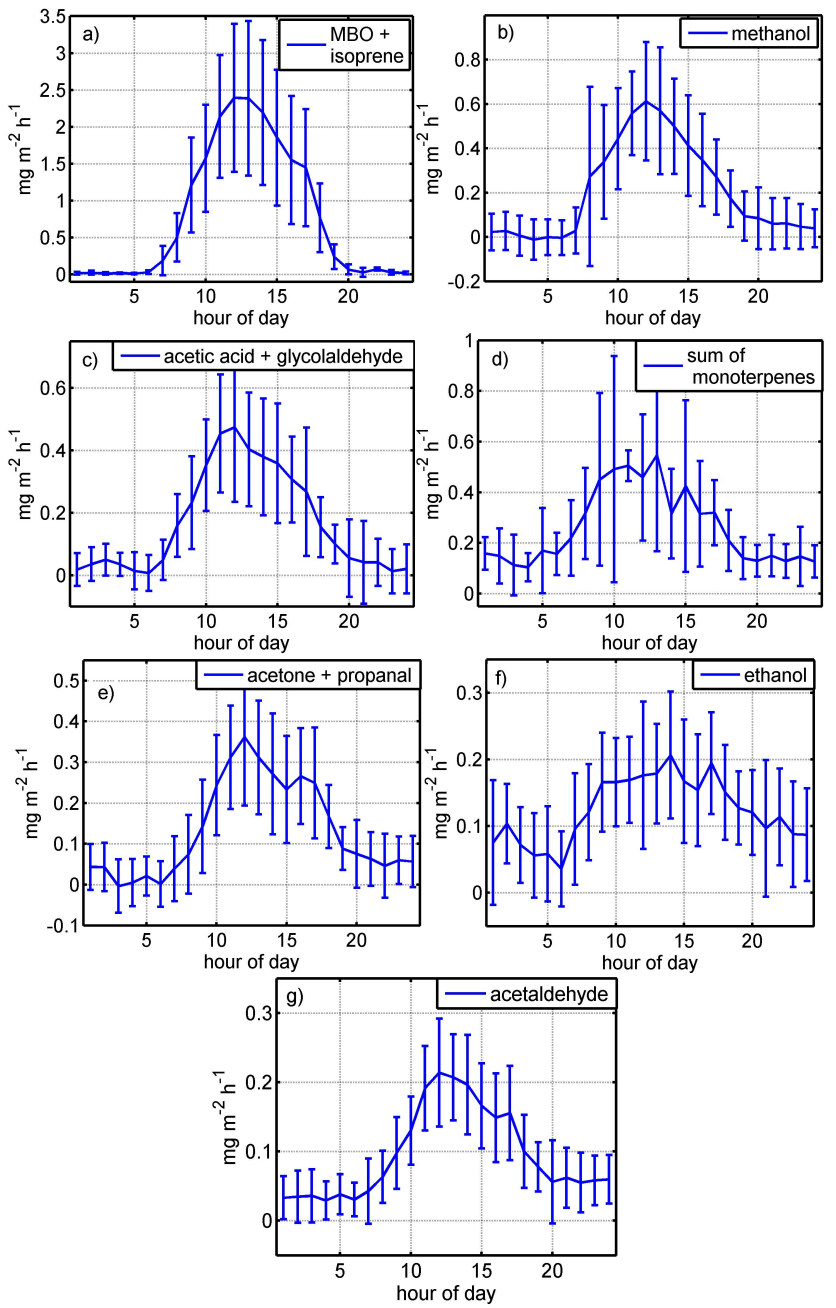

Fig. 4. (a-g) Show averaged diurnal cycles of the 7 VOC species observed to have a significant flux. Data points represent mean values of each half-hour period over the course of the 30 day measurements and the error bars give the standard deviation of that data.

compared with the Harley et al. (1998) leaf level data and the Schade et al. (2001) canopy scale fluxes. We observe an almost perfect agreement of our measurements with the above canopy measurements from Schade et al. (2001) and MEGAN 2.1. The enclosure measurements conducted by Harley et al. (1998) show a higher emission at temperatures $<290 \mathrm{~K}$ but agree with the above canopy measurements within the uncertainty estimates of all studies between 290 $300 \mathrm{~K}$. Table 4 summarizes these results.

To calculate temperature dependencies of other compounds, PAR values below $1000 \mu \mathrm{mol} \mathrm{m}^{-2} \mathrm{~s}^{-1}$ were omitted and the remaining data were binned by each degree of temperature. Results for the temperature fit following the curve $F_{\text {VOC }}=F_{\text {ref }} \cdot \exp \left(\beta\left(T-T_{\text {ref }}\right)\right)$, where $T_{\text {ref }}=303 \mathrm{~K}, F_{\text {ref }}$ the emission at $T_{\text {ref }}$ and $\beta$ the empirical coefficient (listed in Table 5). Additionally, the $Q_{10}$ temperature coefficient is given

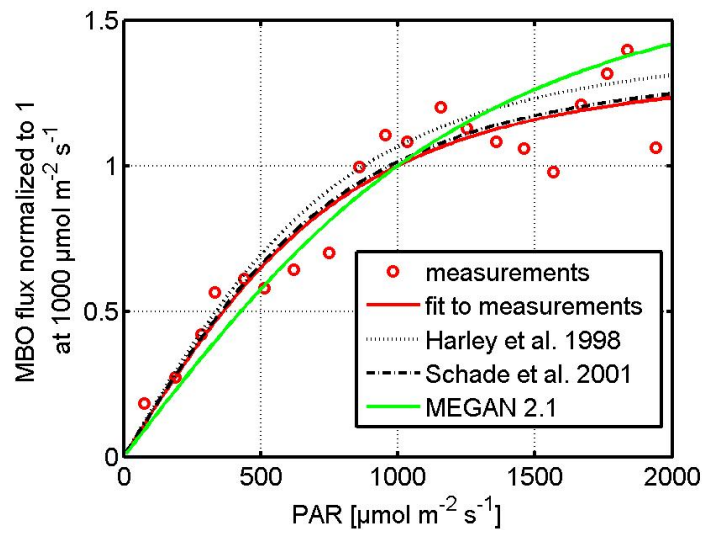

Fig. 5. Light dependence of measurements between $23-27^{\circ} \mathrm{C}$ for the sum of MBO and isoprene emissions. Results from this study (red-solid) are compared to earlier leaf-level results by Harley et al. (1998) (black dot) and canopy-scale results of Schade et al. (2001) (black dash-dot). Red circles represent our measurements averaged into $100 \mu \mathrm{mol} \mathrm{m} \mathrm{m}^{-2} \mathrm{~s}^{-1}$ bins.

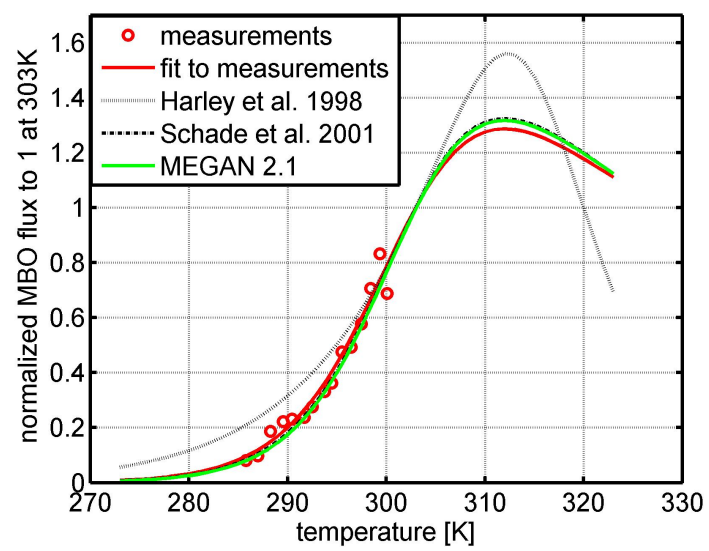

Fig. 6. Temperature dependence of MBO emissions.

as a measure of change in biological reactions driven by a $10^{\circ}$ change in temperature.

Emission of most compounds discussed so far (except ethanol) also show some light dependence. Whether this is due to stomatal conductance or due to a direct light effect cannot be distinguished with these measurements. The results of a linear fit through the data in a temperature range of $23-27^{\circ} \mathrm{C}$ binned in $100 \mu \mathrm{mol} \mathrm{m}{ }^{-2} \mathrm{~s}^{-1}$ light windows are given in Table 6. 
Table 4. Comparison of the empirical coefficients from the temperature-dependent $\mathrm{MBO}$ and isoprene emission following Eq. (2).

\begin{tabular}{lrrrr}
\hline & $\begin{array}{r}\text { Harley et al. } \\
(1998)\end{array}$ & $\begin{array}{r}\text { Schade et al. } \\
(2001)\end{array}$ & This work & MEGAN 2.1 \\
\hline$E_{\text {opt }}$ & 1.54 & 1.45 & $1.29 \pm 0.37$ & 1.32 \\
$C_{T_{1}}$ & 67 & 131 & $128 \pm 33$ & 134 \\
$C_{T_{2}}$ & 209 & 154 & $149 \pm 10$ & 156 \\
$T_{\mathrm{opt}}$ & 312.3 & 312 & 312 (fixed) & 312 \\
\hline
\end{tabular}

Table 5. Temperature-dependent emission factors.

\begin{tabular}{lcccc}
\hline $\begin{array}{l}\text { compound } \\
\left(T_{\text {ref }}=303 \mathrm{~K}\right)\end{array}$ & $\begin{array}{c}F_{\text {ref }} \\
{\left[\mathrm{mg} \mathrm{m}^{-2} \mathrm{~h}^{-1}\right]}\end{array}$ & $\beta$ & $r^{2}$ & $Q_{10}$ \\
\hline $\begin{array}{l}\text { sum of } \\
\text { monoterpenes* }\end{array}$ & $0.50 \pm 0.05$ & $0.12 \pm 0.01$ & 0.85 & 3.32 \\
$\begin{array}{l}\text { methanol } \\
\begin{array}{l}\text { acetone }+ \\
\text { propanal }\end{array}\end{array}$ & $0.94 \pm 0.10$ & $0.13 \pm 0.02$ & 0.81 & 3.67 \\
$\begin{array}{l}\text { acetaldehyde } \\
\text { acetic acid }+\end{array}$ & $0.33 \pm 0.06$ & $0.15 \pm 0.01$ & 0.92 & 4.48 \\
$\begin{array}{l}\text { glycolaldehyde } \\
\text { ethanol }\end{array}$ & $0.91 \pm 0.07$ & $0.15 \pm 0.01$ & 0.94 & 4.48 \\
\hline
\end{tabular}

* For the sum of monoterpenes, only data after DOY 230 were used as the data before this day were significantly affected by the hailstorm.

\subsection{Comparison to MEGAN 2.1 model}

The observed above canopy emissions of the sum of $\mathrm{MBO}$ and isoprene and the sum of monoterpenes are compared with MEGAN 2.1 model results using the landscape average emission factors based on four different approaches: MEGAN 2.1 Southern Rockies Conifers (M21SRC, MEGAN 2.1 average value for the region, including ponderosa pine woodlands and nearby mixed conifer forests), MEGAN 2.1 ponderosa pine (M21PP, MEGAN 2.1 value for ponderosa pine woodlands), site-specific measurements of ponderosa pine (SSLC, measured at MFO using a leaf cuvette), and site-specific measurements of ponderosa pine (SSBE, measured at MFO using a branch enclosure). Landscape average emission factors are the weighted average of species-specific emission factors for all plant species in a landscape. The SSBE and SSLC emission factors use the species composition and vegetation cover fraction observations obtained with ground surveys at the Manitou Forest site. The difference between them is that the SSBE estimate is based on branch enclosure (Teflon bag) measurements and the SSLC estimate is based on leaf cuvette (enclosure using a modified LiCOR 6400) measurements. All of the trees sampled by branch enclosure or leaf cuvette were within the flux tower footprint. The M21SRC and M21PP emission factors use the same species-specific emission factors (based on literature values including Guenther et al. (1994), Harley et
Table 6. Linear fit to light dependency.

\begin{tabular}{lccc}
\hline $\begin{array}{l}\text { compound } \\
\left(T_{\text {ref }}=303 \mathrm{~K}\right)\end{array}$ & Slope & intercept & $r^{2}$ \\
\hline $\begin{array}{l}\text { sum of } \\
\text { monoterpenes* }\end{array}$ & $1.7 \pm 0.3 \times 10^{-4}$ & $0.15 \pm 0.04$ & 0.59 \\
$\begin{array}{l}\text { methanol } \\
\text { acetone }+\end{array}$ & $2.5 \pm 0.2 \times 10^{-4}$ & $0.15 \pm 0.03$ & 0.87 \\
propanal & $1.5 \pm 0.3 \times 10^{-4}$ & $0.11 \pm 0.04$ & 0.53 \\
$\begin{array}{l}\text { acetaldehyde } \\
\text { acetic acid }+\end{array}$ & $6.8 \pm 1.1 \times 10^{-5}$ & $0.11 \pm 0.01$ & 0.67 \\
glycolaldehyde & $2.5 \pm 0.4 \times 10^{-4}$ & $0.09 \pm 0.04$ & 0.70 \\
\hline
\end{tabular}

* For the sum of monoterpenes only data after DOY 230 was used as the data before this day was significantly affected by the hailstorm.

al. (1998), Schade et al. (1999, 2001), and Karl et al., 2002) and the same needle leaf tree cover fraction based on Moderate Resolution Imaging Spectroradiometer (MODIS) satellite land cover estimates (see Guenther et al., 2012). The difference is in the species composition estimated for the Manitou Forest site by the two approaches. The M21SRC estimate uses averaged species composition data for the Southern Rocky Conifer land cover type in the United States Environmental Protection Agency (USEPA) ecoregion scheme, which results in a mixed needle leaf tree species distribution that includes ponderosa and other pine species, Douglas fir, spruce, and fir trees. The M21PP estimate is based on averaged species composition over the Southern Rocky Mountain Ponderosa Pine Woodland land cover type in the United States Geological Survey Gap Analyzing Program (USGS GAP) land cover scheme. Needle leaf trees in this land cover type are dominated by ponderosa pine with a small contribution from Douglas fir, junipers, pinyon pine, and lodgepole pine. The USGS GAP land cover scheme better represents the species composition at the Manitou Forest site. Ambient temperature measured on the chemistry tower at $27 \mathrm{~m}$ height as well as a LAI of 3 and a vegetation cover fraction of 0.38 were used as input for MEGAN 2.1. The emission factors of the four different approaches are listed for the sum of MBO and isoprene and the sum of all reported monoterpenes in Table 7.

Figure 7a compares our $\mathrm{MBO}+$ isoprene measurements with the four model emission types. Current BVOC emission models assume that ponderosa pine emits only MBO and the isoprene emission factor is assumed to be 0. Measured fluxes are represented well by MEGAN 2.1 using the SSLC emission factor. As shown in Fig. 7b, PTR-TOF-MS EC flux measurements and SSLC agree with a slope of 1.07 and $R^{2}$ of 0.83 . The model using the SSBC emission factor is slightly under predicting the measurements, reaching a slope of 0.7. M21SRC and M21PP based on measurements of ponderosa pine from other sites underestimate the measurements with slopes of 0.24 and 0.41 respectively. 
Table 7. Summary of emission factor approaches. The sum of monoterpenes measured by PTR-TOF-MS in this study is compared to the sum of monoterpenes available in MEGAN 2.1: myrcene, sabinene, limonene, 3 -carene, trans- $\beta$-ocimene, $\beta$-pinene, $\alpha$-pinene and other monoterpenes.

\begin{tabular}{l}
$\begin{array}{l}\text { Emission factor } \\
(\mathrm{mg} \text { compound } \\
\left.\mathrm{m}^{-2} \mathrm{~h}^{-1}\right)\end{array}$ \\
\hline $\mathrm{MBO}$ \\
$\begin{array}{l}\text { sum of } \\
\text { monoterpenes }\end{array}$
\end{tabular}
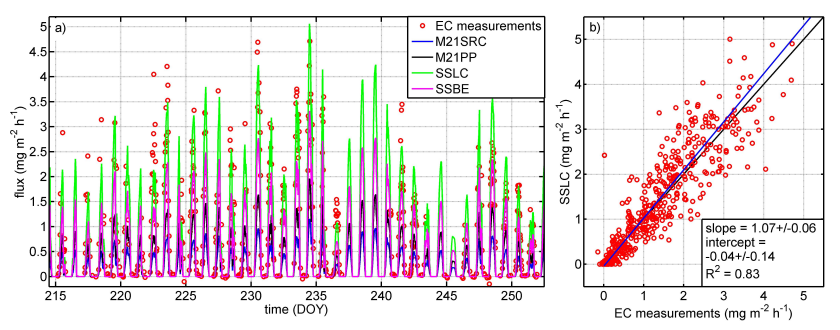

Fig. 7. (a) Emissions for $\mathrm{MBO}+$ isoprene (modeled) and $\mathrm{MBO}+$ isoprene (measured); red circles indicate the measurements, solid lines the four available emission types: M21SRC (MEGAN 2.1 Southern Rockies Conifers), M21PP (MEGAN 2.1 ponderosa pine), SSLC (emission factors from site-specific leaf cuvette measurements), and SSBE (emission factors from site-specific branch enclosure measurements). (b) Scatter plot between PTR-TOF-MS EC flux measurements of $\mathrm{MBO}+$ isoprene and MEGAN 2.1 results using the SSLC emission factor.

Figure 8 compares the PTR-TOF-MS EC flux measurements of monoterpene emissions with the four emission factor approaches. As expected, the hailstorm event (discussed later) is not captured by MEGAN 2.1, using any of the emission types. Additionally, precipitation data are shown in Fig. 8. The highest precipitation was observed on 4 August (day of the hailstorm), reaching $52 \mathrm{~mm}$. The site again experienced significant precipitation on 5 and 10 August. Only two weeks after the hailstorm do model results agree with the measurements. After DOY 240, all emission factor approaches agree similarly well with an $R^{2}$ of 0.68 and slopes between $0.57-0.77$.

\subsection{The hailstorm event}

On 4 August a severe hailstorm impacted the site. Hailstones of about $1-3 \mathrm{~cm}$ in diameter caused damage to needles and branches. As a result, 22 ion mass peaks showed an elevated flux signal. All ion mass peaks are given in Table 8; they are grouped into their likely compound classes and sorted by descending amount of emission. Assignments of exact ion mass peaks to compounds/compound classes were made using the

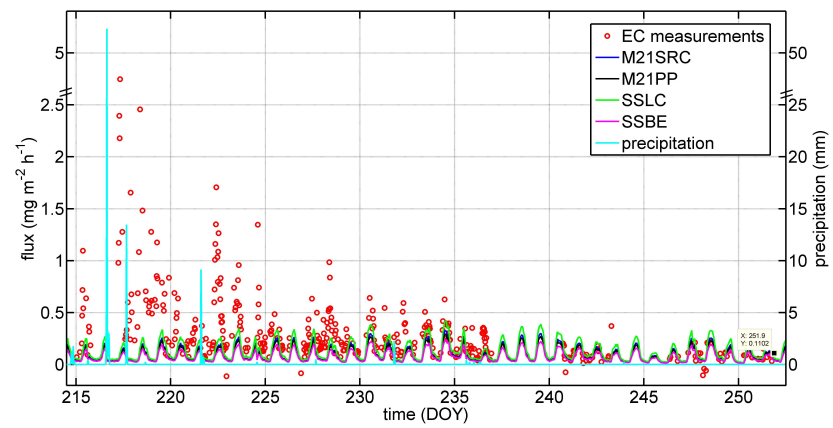

Fig. 8. Emissions for the sum of monoterpenes: red circles indicate the measurements, solid lines the four available emission factor approaches used in MEGAN 2.1 to model the emissions. Precipitation in $\mathrm{mm}$ is given for references (cyan line).

work of Kim et al. (2010) and references therein. Especially interesting is that we also observe first order oxidation products of monoterpenes such as pinonaldehyde and nopinone exhibiting an elevated flux after the hailstorm. At this point we cannot determine whether this results from increased incanopy overall oxidation rates or if this is due to direct emission from the wounded branches and needles.

The sum of monoterpenes shows by far the highest emission with a maximum of $4.75 \mathrm{mg} \mathrm{m}^{-2} \mathrm{~h}^{-1}$. This corresponds to a 4-times higher maximum flux as observed on the day before the hailstorm. If we use MEGAN 2.1 to calculate the regular (temperature and light) dependent flux on the day after the hailstorm and compare this to the measurements, the observed flux is $\sim 23$ times higher. This is justified as the measurements on 3 August (day before the hailstorm) might still be influenced from a hailstorm on 27 July. Figure 9 shows the maximum of emission before and after the hailstorm (3 August and 5 August) for all compounds that show a flux during the 30 day average as well as those that are influenced by the hailstorm. The fluxes of $\mathrm{MBO}+$ isoprene as well as the flux of the sum of monoterpenes are also compared to the expected flux calculated by MEGAN 2.1, based on the emission factors calculated for this work (see Sect. 3.4, Table 7). Elevated monoterpene concentrations and fluxes after mechanical wounding have been previously observed (Bouvier-Brown et al., 2009; Haase et al., 2011; Bamberger et al., 2011; Holzinger et al., 2006). New in this study is that a natural event such as a hailstorm can cause such a strong mechanical damage to enhance monoterpene emissions by a factor of 4-23 as well as the enhancement of several other compounds such as cymene, camphor, nopinone, pinonaldehyde and the sum of sesquiterpenes. Some compounds such as the sum of sesquiterpenes as well as the flux measured on $m / z 105.070$ show a maximum of elevation only two days after the hailstorm, as indicated in Fig. 9.

Figure 10 shows the concentrations (upper panel) and fluxes (lower panel) of the sum of monoterpenes (red) and the sum of MBO and isoprene (blue) for the whole 
Table 8. List of ion mass peaks that show an elevated flux after the hailstorm on 4 August. If possible they were grouped into compound classes and sorted by the amount of maximum emission after the hailstorm. The remaining ion mass peaks are listed at the end of the table by decreasing molecular weight.

\begin{tabular}{|c|c|c|}
\hline $\begin{array}{l}\text { Molecular } \\
\text { formula }\end{array}$ & $\begin{array}{l}\text { Likely } \\
\text { compound }\end{array}$ & Exact masses $(m / z)$ \\
\hline $\mathrm{C}_{10} \mathrm{H}_{16}-\mathrm{H}^{+}$ & $\begin{array}{l}\text { sum of } \\
\text { monoterpenes }\end{array}$ & $\begin{array}{l}137.134 \text { (parent ion) } \\
138.137 \text { (isotope) } \\
81.0706 \text { (fragment) } \\
82.0738 \text { (isotope) } \\
95.0866 \text { (fragment) }\end{array}$ \\
\hline $\mathrm{C}_{10} \mathrm{H}_{14}-\mathrm{H}^{+}$ & p-cymene & $\begin{array}{l}135.118 \text { (parent ion) } \\
136.13 \text { (isotope) } \\
93.0707 \text { (fragment) }\end{array}$ \\
\hline $\mathrm{C}_{10} \mathrm{H}_{16} \mathrm{O}-\mathrm{H}^{+}$ & e.g., camphor & $\begin{array}{l}153.128 \text { (parent ion) } \\
154.132 \text { (isotope) }\end{array}$ \\
\hline $\mathrm{C}_{10} \mathrm{H}_{16} \mathrm{O}_{2}-\mathrm{H}^{+}$ & Pinonaldehyde & $\begin{array}{l}169.124 \text { (parent ion) } \\
151.113 \text { (fragment) } \\
109.105 \text { (fragment) } \\
107.086 \text { (fragment) } \\
99.081 \text { (fragment) }\end{array}$ \\
\hline $\mathrm{C}_{9} \mathrm{H}_{14} \mathrm{O}-\mathrm{H}^{+}$ & Nopinone & $\begin{array}{l}139.117 \text { (parent ion) } \\
121.098 \text { (fragment) }\end{array}$ \\
\hline $\mathrm{C}_{15} \mathrm{H}_{24}-\mathrm{H}^{+}$ & $\begin{array}{l}\text { sum of } \\
\text { sesquiterpenes }\end{array}$ & $\begin{array}{l}205.198 \text { (parent ion) } \\
95.0866 \text { (fragment) }\end{array}$ \\
\hline $\mathrm{C}_{8} \mathrm{H}_{8}-\mathrm{H}^{+}$ & e.g., styrene & 105.070 (parent ion) \\
\hline
\end{tabular}

Several still unassigned ion mass peaks that also had elevated fluxes after the hailstorm:

\begin{tabular}{lll}
\hline $\mathrm{C}_{7} \mathrm{H}_{10} \mathrm{O}_{3}-\mathrm{H}^{+}$ & $\begin{array}{l}\text { Unknown (one } \\
\text { possibility: } \\
\end{array}$ & 143.069 \\
& homofuraneol) & \\
\hline $\mathrm{C}_{7} \mathrm{H}_{10} \mathrm{O}_{2}-\mathrm{H}^{+}$ & Unknown & 127.077 \\
\hline
\end{tabular}

measurement period. After the hailstorm on 4 August (DOY 216), monoterpene volume mixing ratios and fluxes are elevated. In contrast, the sum of MBO + isoprene is not elevated after the hailstorm. Some monoterpenes are stored in pools and due to the wounding of the pools are released in higher amounts. MBO + isoprene are not stored but emitted directly after their production. Higher emissions of stored compounds could be induced by mechanical wounding of the trees.

Figure 11 shows the cumulative flux calculated from the measurements (blue) and the expected flux, assuming only temperature- and light dependencies using MEGAN 2.1 (red) adjusted to the measurements at the end of the measurement campaign when we assume no more influence of the hailstorm (after DOY 240). This indicates that if monoterpene emissions are calculated based on temperature- and light de-
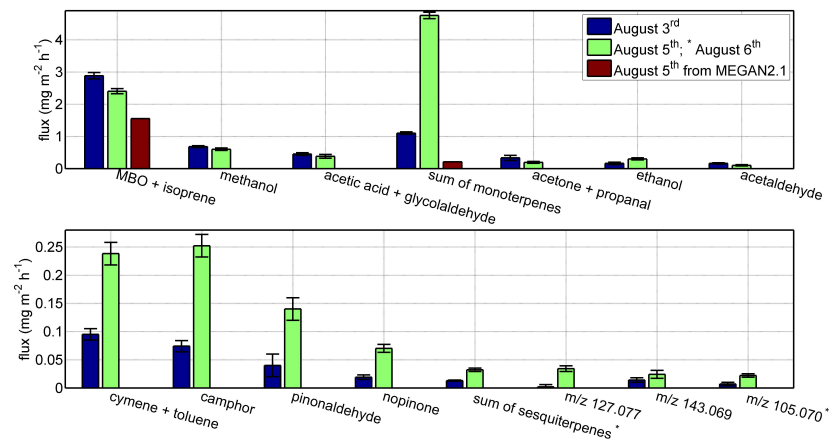

Fig. 9. Comparison of the fluxes on the day after the hailstorm with measured fluxes on the day before the hailstorm as well as the calculated flux from MEGAN 2.1 using emission factors calculated from this work (see Table 7). Error bars represent the random flux error of eddy covariance calculation.
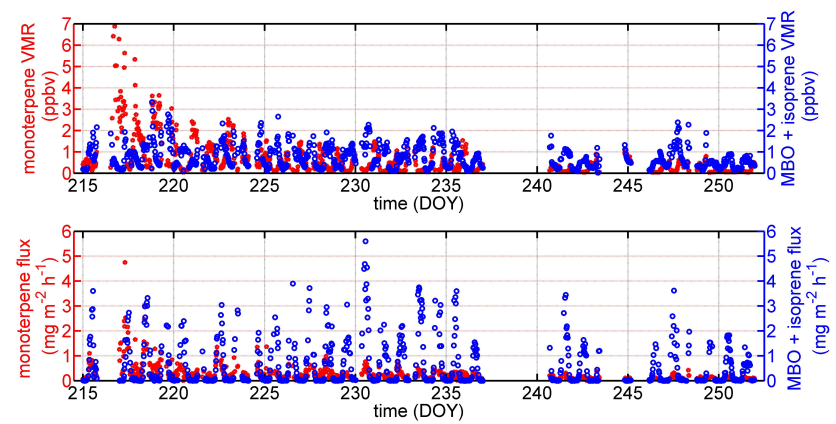

Fig. 10. Volume mixing ratios of monoterpenes (red) and the sum of $\mathrm{MBO}+$ isoprene (blue) are shown for the entire measurement period in the upper panel. The lower panel shows fluxes for the same species and time. The hailstorm occurred on 4 August (DOY 216).

pendence, only then the cumulative flux over one month is underestimated by $\sim 40 \%$.

\section{Summary and conclusion}

Eddy covariance PTR-TOF-MS measurements above a ponderosa pine forest in Colorado, USA, revealed fluxes of 17 ion mass peaks that can be grouped into seven compound classes. The sum of MBO and isoprene is the dominant flux, contributing $50 \%$ to the total observed flux. The other compounds showing a significant daily flux are methanol, the sum of acetic acid and glycolaldehyde, the sum of monoterpenes, the sum of acetone and propanal, and ethanol.

Temperature- and light dependence of $\mathrm{MBO}+$ isoprene are found to be in good agreement with previous measurements. Eddy covariance measurements of $\mathrm{MBO}+$ isoprene and the sum of monoterpenes are compared to four different emission factor estimation approaches available for MEGAN 2.1 at this site. The emission factor obtained from site-specific leaf cuvette emission measurements and tree 


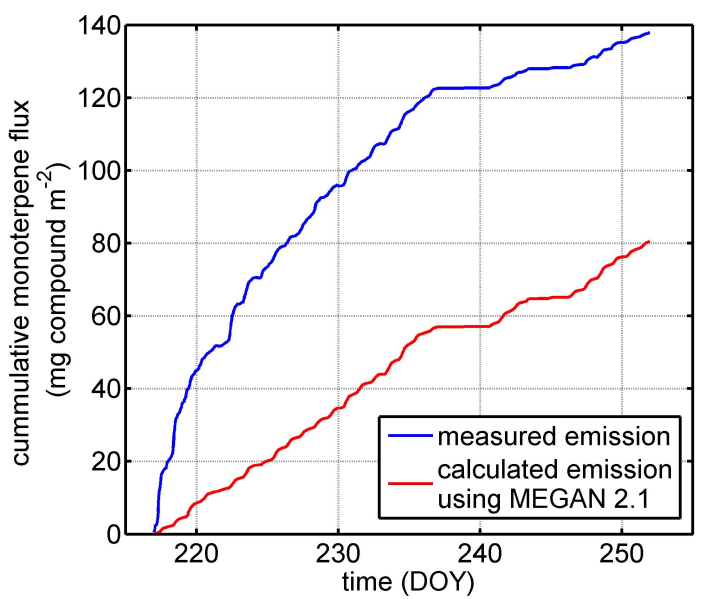

Fig. 11. Cumulative monoterpene flux calculated from the 30 day measurement period (blue) and cumulative monoterpene flux based on MEGAN 2.1 assuming only temperature- and light dependence (red).

cover surveys agree best with the above canopy flux measurements.

The wounding of branches and needles due to a severe hailstorm triggered the emission of monoterpenes and other compounds such as camphor, pinonaldehyde, nopinone and sesquiterpenes. The storm increased the monthly emissions of monoterpenes by $40 \%$ compared to model results, assuming only temperature- and light-dependent emission. These results stress the importance of long-term above canopy flux measurements to increase the chance to capture irregularly occurring events such as hailstorms, which can significantly influence the budget of VOCs emitted from a needle tree forest.

Acknowledgements. This work was financially supported by the Austrian Science Fund (FWF) under the project number L518-N20. The National Center for Atmospheric Research is operated by the University Corporation for Atmospheric Research under sponsorship from the National Science Foundation. L. Kaser is a recipient of a DOC-fFORTE-fellowship of the Austrian Academy of Science. This work was also supported by the EC Seventh Framework Program (Marie Curie Reintegration Program, "ALPAIR", grant no. 334084) to T. K. F. N. Keutsch wishes to thank the National Science Foundation for financial support (ATM 0852406). The authors would like to thank the BEACHON ROCS science team that assured the success of this measurement campaign.

Edited by: J. Rinne

\section{References}

Arneth, A. and Niinemets, Ü.: Induced BVOCs: How to bug our models?, Trends Plant Sci., 15, 118-125, doi:10.1016/j.tplants.2009.12.004, 2010.
Bamberger, I., Hörtnagl, L., Tuuskanen, T. M., Schnitzhofer, R., Müller, M., Graus, M., Karl, T., Wohlfahrt, G., and Hansel, A.: Deposition fluxes of terpenes over grassland, J. Geophys. Res., 116, D14305, doi:10.1029/2010JD015457, 2011.

Bouvier-Brown, N. C., Goldstein, A. H., Gilman, J. B., Kuster, W. C., and de Gouw, J. A.: In-situ ambient quantification of monoterpenes, sesquiterpenes, and related oxygenated compounds during BEARPEX 2007: implications for gas- and particle-phase chemistry, Atmos. Chem. Phys., 9, 5505-5518, doi:10.5194/acp-9-5505-2009, 2009.

DiGangi, J. P., Boyle, E. S., Karl, T., Harley, P., Turnipseed, A., Kim, S., Cantrell, C., Maudlin III, R. L., Zheng, W., Flocke, F., Hall, S. R., Ullmann, K., Nakashima, Y., Paul, J. B., Wolfe, G. M., Desai, A. R., Kajii, Y., Guenther, A., and Keutsch, F. N.: First direct measurements of formaldehyde flux via eddy covariance: implications for missing in-canopy formaldehyde sources, Atmos. Chem. Phys., 11, 10565-10578, doi:10.5194/acp-1110565-2011, 2011.

Duhl, T. R., Gochis, D., Guenther, A., Ferrenberg, S., and Pendall, E.: Emissions of BVOC from lodgepole pine in response to mountain pine beetle attack in high and low mortality forest stands, Biogeosciences, 10, 483-499, doi:10.5194/bg-10-4832013, 2013.

Fischer, L., Klinger, A., Herbig, J., Winkler, K., Gutmann, R., and Hansel, A.: The LCU: Versatile Trace Gas Calibration, in: 6th International Conference on Proton Transfer Reaction Mass Spectrometrz and its Applications Proceedings, 192-194, 2013.

Foken, T. and Wichura, B.: Tools for quality assessment of surfacebased flux measurements, Agr. Forest Meteorol., 78, 83-105, 1996.

Fowler, D., Pilegaard, K., Sutton, M. A., Ambus, P., Raivonen, M., Duyzer, J., Simpson, D., Fagerli, H., Fuzzi, S., Schjoerring, J. K., Granier, C., Neftl, A., Isaksen, I. S. A., Laj, P., Maione, M., Monks, P. S., Burkhardt, J., Daemmgen, U., Neirynck, J., Personne, E., Wichink-Kruit, R., Butterbach-Bahl, K., Flechard, C., Tuovinen, J. P., Coyle, M., Gerosa, G., Loubet, B., Altimir, N., Gruenhage, L., Ammann, C., Cieslik, S., Paoletti, E., Mikkelsen, T. N., Ro-Poulsen, H., Cellier, P., Cape, J. N., Horvath, L., Loreto, F., Niinemets, U., Palmer, P. I., Rinne, J., Misztal, P., Nemitz, E., Nilsson, D., Pryor, S., Gallagher, M. W., Vesala, T., Skiba, U., Bruggemann, N., Zechmeister-Boltenstern, S., Williams, J., O'Dowd, C., Facchini, M. C., de Leeuw, G., Flossman, A., Chaumerliac, N., and Erisman, J. W.: Atmospheric composition change: Ecosystems-Atmosphere interactions, Atmos. Environ., 43, 5193-5267, 2009.

Graham, R. and Jain, T.: Ponderosa Pine Ecosystems, USDA Forest Service Gen. Tech. Rep. PSW-GTR-198, 2005.

Graus, M., Müller, M., and Hansel, A.: High Resolution PTRTOF: Quantification and Formula Confirmation of VOC in Real Time, J. Am. Soc. Mass. Spectr., 21, 1037-1044, doi:10.1016/j.jasms.2010.02.006, 2010.

Grote, R. and Niinemets, Ü.: Modeling volatile isoprenoid emissions - A story with split ends, Plant Biol., 10, 8-28, doi:10.1055/s-2007-964975, 2008.

Guenther, A.: The contribution of reactive carbon emissions from vegetation to the carbon balance of terrestrial ecosystems, Chemosphere, 49, 837-844, 2002. 
Guenther, A., Zimmerman, P., and Wildermuth, M.: Natural Volatile Organic-Compound Emission Rate Estimates for United-States Woodland Landscapes, Atmos. Environ., 28, 1197-1210, 1994.

Guenther, A., Hewitt, C. N., Erickson, D., Fall, R., Geron, C., Graedel, T., Harley, P., Klinger, L., Lerdau, M., Mckay, W. A., Pierce, T., Scholes, B., Steinbrecher, R., Tallamraju, R., Taylor, J., and Zimmermann, P.: A global-model of natural volatile organic-compound emissions, J. Geophys. Res.-Atmos., 100, 8873-8892, 1995.

Guenther, A., Karl, T., Harley, P., Wiedinmyer, C., Palmer, P. I., and Geron, C.: Estimates of global terrestrial isoprene emissions using MEGAN (Model of Emissions of Gases and Aerosols from Nature), Atmos. Chem. Phys., 6, 3181-3210, doi:10.5194/acp-63181-2006, 2006.

Guenther, A. B., Jiang, X., Heald, C. L., Sakulyanontvittaya, T., Duhl, T., Emmons, L. K., and Wang, X.: The Model of Emissions of Gases and Aerosols from Nature version 2.1 (MEGAN 2.1): an extended and updated framework for modeling biogenic emissions, Geosci. Model Dev., 5, 1471-1492, doi:10.5194/gmd5-1471-2012, 2012.

Haase, K. B., Jordan, C., Mentis, E., Cottrell, L., Mayne, H. R., Talbot, R., and Sive, B. C.: Changes in monoterpene mixing ratios during summer storms in rural New Hampshire (USA), Atmos. Chem. Phys., 11, 11465-11476, doi:10.5194/acp-1111465-2011, 2011.

Harley, P., Fridd-Stroud, V., Greenberg, J., Guenther, A., and Vasconcellos, P.: Emission of 2-methyl-3-buten-2-ol by pines: A potentially large natural source of reactive carbon to the atmosphere, J. Geophys. Res., 103, 25479-25486, 1998.

Helmig, D., Greenberg, J., Guenther, A., Zimmerman, P., and Geron, C.: Volatile organic compounds and isoprene oxidation products at a temperate deciduous forest site, J. Geophys. Res.Atmos., 103, 22397-22414, 1998.

Hsieh, C. I., Katul, G., and Chi, T.: An approximate analytical model for footprint estimation of scalar fluxes in thermally stratified atmospheric flows, Adv. Water Resour., 23, 765-772, 2000.

Holopainen, J. K. and Gershenzon, J.: Multiple stress factors and the emission of plant VOCs, Trends Plant Sci., 15, 176-184, 2010.

Holzinger, R., Lee, A., McKay, M., and Goldstein, A. H.: Seasonal variability of monoterpene emission factors for a ponderosa pine plantation in California, Atmos. Chem. Phys., 6, 1267-1274, doi:10.5194/acp-6-1267-2006, 2006.

Jordan, A., Haidacher, S., Hanel, G., Hartungen, E., Märk, L., Seehauser, H., Schottkowsky, R., Sulzer, P., and Märk, T. D.: A high resolution and high sensitivity proton-transfer-reaction time-offlight mass spectrometer (PTR-TOF-MS), Int. J. Mass Spectrom., 286, 122-128, 2009.

Karl, T. G., Spirig, C., Rinne, J., Stroud, C., Prevost, P., Greenberg, J., Fall, R., and Guenther, A.: Virtual disjunct eddy covariance measurements of organic compound fluxes from a subalpine forest using proton transfer reaction mass spectrometry, Atmos. Chem. Phys., 2, 279-291, doi:10.5194/acp-2-279-2002, 2002.

Kaser, L., Karl, T., Schnitzhofer, R., Graus, M., Herdlinger-Blatt, I. S., DiGangi, J. P., Sive, B., Turnipseed, A., Hornbrook, R. S., Zheng, W., Flocke, F. M., Guenther, A., Keutsch, F. N., Apel, E., and Hansel, A.: Comparison of different real time VOC measurement techniques in a ponderosa pine forest, Atmos. Chem. Phys., 13, 2893-2906, doi:10.5194/acp-13-2893-2013, 2013.
Kesselmeier, J. and Staudt, M.: Biogenic volatile organic compounds (VOC): An overview on emission, physiology and ecology, J. Atmos. Chem., 33, 23-88, 1999.

Kim, L., Galbally, I. E., Porter, N., Weeks, I. A., and Lawson, S. $\mathrm{J} .:$ BVOC emissions from mechanical wounding of leaves and branches of Eucalyptus sideroxylon (red ironbark), J. Atmos. Chem., 68, 265-279, doi:10.1007/s10874-012-9221-x, 2011.

Kim, S., Karl, T., Guenther, A., Tyndall, G., Orlando, J., Harley, P., Rasmussen, R., and Apel, E.: Emissions and ambient distributions of Biogenic Volatile Organic Compounds (BVOC) in a ponderosa pine ecosystem: interpretation of PTR-MS mass spectra, Atmos. Chem. Phys., 10, 1759-1771, doi:10.5194/acp-101759-2010, 2010.

Koppmann, R.: Volatile Organic Compounds in the Atmosphere, Oxford, Blackwell Publishing, 2007.

Lamarque, J.-F., Bond, T. C., Eyring, V., Granier, C., Heil, A., Klimont, Z., Lee, D., Liousse, C., Mieville, A., Owen, B., Schultz, M. G., Shindell, D., Smith, S. J., Stehfest, E., Van Aardenne, J., Cooper, O. R., Kainuma, M., Mahowald, N., McConnell, J. R., Naik, V., Riahi, K., and van Vuuren, D. P.: Historical (1850-2000) gridded anthropogenic and biomass burning emissions of reactive gases and aerosols: methodology and application, Atmos. Chem. Phys., 10, 7017-7039, doi:10.5194/acp10-7017-2010, 2010.

Lee, A., Schade, G. W., Holzinger, R., and Goldstein, A. H.: A comparison of new measurements of total monoterpene flux with improved measurements of speciated monoterpene flux, Atmos. Chem. Phys., 5, 505-513, doi:10.5194/acp-5-505-2005, 2005.

McMillen, R. T.: An eddy correlation technique with extended applicability to non-simple terrain, Bound.-Lay. Meteorol., 43, 231-245, 1988

Muller, J. F.: Geographical-Distribution and Seasonal-Variation of Surface Emissions and Deposition Velocities of Atmospheric Trace Gases, J. Geophys. Res.-Atmos., 97, 3787-3804, 1992.

Müller, M., Graus, M., Ruuskanen, T. M., Schnitzhofer, R., Bamberger, I., Kaser, L., Titzmann, T., Hörtnagl, L., Wohlfahrt, G., Karl, T., and Hansel, A.: First eddy covariance flux measurements by PTR-TOF, Atmos. Meas. Tech., 3, 387-395, doi:10.5194/amt-3-387-2010, 2010.

Niinemets, Ü.: Mild versus severe stress and BVOCs: thresholds priming and consequences, Trends Plant Sci., 15, 145-153, 2010.

Niinemets, Ü., Monson, R. K., Arneth, A., Ciccioli, P., Kesselmeier, J., Kuhn, U., Noe, S. M., Peñuelas, J., and Staudt, M.: The leaflevel emission factor of volatile isoprenoids: caveats, model algorithms, response shapes and scaling, Biogeosciences, 7, 18091832, doi:10.5194/bg-7-1809-2010, 2010a.

Niinemets, Ü., Arneth, A., Kuhn, U., Monson, R. K., Peñuelas, J., and Staudt, M.: The emission factor of volatile isoprenoids: stress, acclimation, and developmental responses, Biogeosciences, 7, 2203-2223, doi:10.5194/bg-7-2203-2010, 2010 b.

Olivier, J. G. J., Bloos, J. P. J., Berdowski, J. J. M., Visschedijk, A. J. H., and Bouwman, A. R.: A 1990 global emission inventory of anthropogenic sources of carbon monoxide on $1^{\circ} \times 1^{\circ}$ developed in the framework of EDGAR/GEIA, Chemosphere, 1, 1-17, 1999.

Park, J.-H., Goldstein, A. H., Timkovsky, J., Fares, S., Weber, R., Karlik, J., and Holzinger, R.: Eddy covariance emission and deposition flux measurements using proton transfer reaction - time 
of flight - mass spectrometry (PTR-TOF-MS): comparison with PTR-MS measured vertical gradients and fluxes, Atmos. Chem. Phys., 13, 1439-1456, doi:10.5194/acp-13-1439-2013, 2013.

Räisänen, T., Ryyppö, A., and Kellomäki, S.: Impact of timber felling on the ambient monoterpene concentration of a Scots pine (Pinus sylvestris L.) forest, Atmos. Environ., 42, 6759-6766, 2008.

Ruuskanen, T. M., Müller, M., Schnitzhofer, R., Karl, T., Graus, M., Bamberger, I., Hörtnagl, L., Brilli, F., Wohlfahrt, G., and Hansel, A.: Eddy covariance VOC emission and deposition fluxes above grassland using PTR-TOF, Atmos. Chem. Phys., 11, 611-625, doi:10.5194/acp-11-611-2011, 2011.

Schade, G. E., Goldstein, A. H., and Lamanna, M. S.: Are monoterpene Emissions influenced by Humidity?, Geophys. Res. Lett., 26, 2187-2190, 1999.
Schade, G. W. and Goldstein, A. H.: Fluxes of oxygenated volatile organic compounds from a ponderosa pine plantation, J. Geophys. Res. A., 106, 3111-3123, 2001.

Schade, G. W. and Goldstein, A. H.: Increase of monoterpene emissions from a pine plantation as a result of mechanical disturbances, Geophys. Res. Lett., 30, 1380, doi:10.1029/2002GL016138, 2003.

Wilczak, J. M., Oncley, S. P., and Stange, S. A.: Sonic anemometer tilt correction algorithms, Bound.-Lay. Meteorol., 99, 127-150, 2001. 